\title{
Evolution of Durable High-Strength Flowable Mortar Reinforced with Hybrid Fibers
}

\author{
Eethar Thanon Dawood ${ }^{1}$ and Mahyuddin Ramli ${ }^{2}$ \\ ${ }^{1}$ Building and Construction Department, Technical College of Mosul, Mosul, Iraq \\ ${ }^{2}$ School of Housing, Building and Planning, Universiti Sains Malaysia, 11800 Penang, Malaysia \\ Correspondence should be addressed to Eethar Thanon Dawood, eethar2005@yahoo.com
}

Received 17 February 2012; Accepted 22 April 2012

Academic Editors: P. J. S. Cruz, M. Maslehuddin, and I. Raftoyiannis

Copyright (C) 2012 E. T. Dawood and M. Ramli. This is an open access article distributed under the Creative Commons Attribution License, which permits unrestricted use, distribution, and reproduction in any medium, provided the original work is properly cited.

\begin{abstract}
The production and use of durable materials in construction are considered as one of the most challenging things for the professional engineers. Therefore, this research was conducted to investigate the mechanical properties and the durability by using of different percentages of steel fiber with high-strength flowable mortar (HSFM) and also the use of the hybridization of steel fibers, palm fibers, and synthetic fiber (Barchip). Different experimental tests (compressive strength, splitting tensile strength, flexural strength, and static modulus of elasticity among others) were determined after 90 days of normal water curing and 180 days of seawater exposure. The results indicate that hybrid fibers of $1.5 \%$ steel fibers $+0.25 \%$ palm fibers $+0.25 \%$ Barchip fibers provide significant improvement in the different mechanical properties of HSFM. Besides, the hybridization of fibers was found to be effective in the terms of durability (exposure to seawater). Therefore, the minimum reduction in static modulus of elasticity, compressive, splitting and flexural strength was obtained for the HSFM mixes of hybrid fibers using steel fibers with palm fibers and also for the use of steel, palm, and Barchip fibers.
\end{abstract}

\section{Introduction}

High-strength concrete or mortar subjected to axial compression is known to be a brittle material with almost no strain-softening behavior. Adding fibers to plain matrix has little or no effect on its precracking behavior but does substantially enhance its postcracking response, which leads to a greatly improved toughness and impact behavior [1]. Besides that, ductility in fiber reinforced cementitious composites is enhanced because fibers bridge crack surface and delay the onset of the extension of cracks [2].

Shah and Naaman [3] investigated tensile strength, flexural strength, and compressive strength tests on mortar specimens reinforced with steel fibers. It was observed that the tensile or flexural strength of steel fiber-reinforced mortar was at least two to three times higher than that of plain mortar. However, the addition of steel fibers at higher dosages has some disadvantages in terms of poor workability and higher cost. In addition, the high stiffness of steel fibers in the matrix means that voids and honeycombs could be formed during placing as a result of improper compaction at low workability. In order for good flow ability of mortar, the addition of two or three different fiber types can yield the optimum performance $[4,5]$.

Sustersic et al. [6] stated that the effect of corrosion of surface steel fibers is not detrimental to fiber-reinforced cement composites under field conditions. However, in their study, the creation of weak zones on the surface of specimens due to corrosion of steel fibers caused surface cracking at low-stress levels and opened direct paths for the ingress of aggressive media. This shows that caution is required when considering applications using steel fiber-reinforced cement composites in aggressive chemical environments, especially under sustained combined flexural loading and wettingdrying conditions.

Therefore, the objective of this paper is to determine the basic characteristics of high-strength flowable mortar (HSFM) reinforced by steel fibers as well as the hybridization 
TABLE 1: Chemical composition of ordinary portland cement and silica fume.

\begin{tabular}{lcc}
\hline Constituent & $\begin{array}{c}\text { Ordinary portland } \\
\text { cement }\end{array}$ & Silica fume \\
& Percentage by weight & Percentage by weight \\
\hline Lime $(\mathrm{CaO})$ & 64.64 & $1.0 \%(\max )$ \\
Silica $\left(\mathrm{SiO}_{2}\right)$ & 21.28 & $90 \%(\max )$ \\
Alumina $\left(\mathrm{Al}_{2} \mathrm{O}_{3}\right)$ & 5.60 & $1.2 \%(\max )$ \\
Iron oxide $\left(\mathrm{Fe}_{2} \mathrm{O}_{3}\right)$ & 3.36 & $2.0 \%(\max )$ \\
Magnesia $\left(\mathrm{MgO}^{2}\right)$ & 2.06 & $0.6 \%(\max )$ \\
Sulphur trioxide $\left(\mathrm{SO}_{3}\right)$ & 2.14 & $0.5 \%(\max )$ \\
$\mathrm{N}_{2} \mathrm{O}$ & 0.05 & $0.8 \%(\max )$ \\
Loss of ignition & 0.64 & $6 \%(\max )$ \\
Lime saturation factor & 0.92 & - \\
$\mathrm{C} 3 \mathrm{~S}$ & 52.82 & - \\
$\mathrm{C} 2 \mathrm{~S}$ & 21.45 & - \\
$\mathrm{C} 3 \mathrm{~A}$ & 9.16 & - \\
$\mathrm{C} 4 \mathrm{AF}$ & 10.2 & - \\
\hline
\end{tabular}

TABle 2: Physical properties of palm fiber.

\begin{tabular}{lc}
\hline Fiber Properties & Quantity \\
\hline Average fiber length (mm) & 30 \\
Average fiber width, micron & 21.13 \\
Tensile strength $(\mathrm{MPa})$ & 21.2 \\
Elongation at break (\%) & 0.04 \\
Specific gravity & 1.24 \\
Water absorption (\%), 24/48 hrs & 0.6 \\
\hline
\end{tabular}

of three different type of fibers namely, steel fibers, palm fibers, and synthetic fibers (Barchip fibers) in terms of compressive strength, splitting tensile strength, flexural strength, modulus of elasticity, ultrasonic pulse velocity test, absorption and voids ratio. Consequently, these mechanical properties of the specimens of HSFM have been tested after exposure to seawater to study the durability of HSFM reinforced by fibers.

\section{Materials and Mix Proportions}

2.1. Materials. The cement used in concrete mixtures was ordinary Portland cement type I from Tasek Corporation Berhad. Silica fume was obtained from Scancem Materials Sdn. Bhd. and was used as a partial replacement for cement. The chemical compositions of ordinary Portland cement and silica fume are given in Table 1.

The superplasticizer (SP) is Conplast SP1000 obtained from Fosroc Sdn. Bhd. and was used to establish the desired workability of mixes. The fine aggregate was natural sand, with fineness modulus of 2.86 and maximum size of less than $5 \mathrm{~mm}$. The palm fiber was supplied by Fiber-X (M) Sdn. Bhd, and their characteristics are shown in Table 2. The synthetic fiber (Barchip) was obtained from elastoplastic concrete, and its characteristics are presented in Table 3 . The steel fiber is
TABle 3: Physical properties of synthetic fiber (Barchip).

\begin{tabular}{lc}
\hline Fiber properties & Quantity \\
\hline Average fiber length $(\mathrm{mm})$ & 30 \\
Average fiber width $(\mathrm{mm})$ & 0.52 \\
Tensile strength $(\mathrm{MPa})$ & 550 \\
Young's modulus $(\mathrm{GPa})$ & 8.2 \\
Specific gravity & 0.92 \\
Melting point $\left({ }^{\circ} \mathrm{C}\right)$ & $150-165$ \\
\hline \multicolumn{2}{c}{ TABLE $4:$ Physical properties of steel fiber. } \\
\\
\hline Fiber Properties \\
\hline Average fiber length, $(\mathrm{mm})$ & \\
Average fiber diameter, $(\mathrm{mm})$ & 30 \\
Aspect ratio $(\mathrm{L} / \mathrm{d})$ & 0.56 \\
Tensile strength $(\mathrm{MPa})$ & 54 \\
Ultimate elongation $(\%)$ & $>1100$ \\
Specific gravity & $<2$ \\
\hline
\end{tabular}

supplied by Hunan Sunshine Steel Fiber Co. Ltd, and their mechanical properties are shown in Table 4 .

2.2. Mix Proportions. The mixes proportions of the different mortar mixes are given in Table 5. A total of seventeen mortar mixes were prepared using water-binder (cement + silica fume) ratio of 0.43 , and silica fume replacement was $10 \%$. The amount of cement, silica fume, sand and free water was kept constant. The amount of superplasticizer was varied from $1.8 \%$ to $2.2 \%$ by weight of binder materials to maintain the workability and the uniformity of the mixes. The mix design of the control mix (M0) is carried out according to the absolute volume method given by the American Concrete Institute (ACI 211.1) [7] for the flowable high-strength mortar. The steel fibers varied from $0.25 \%$ to $2 \%$ to prepare the mixes M1 to M8. However, the use of hybrid fibers of steel and palm fibers with constant fiber volume fractions ( $2 \%$ vol.) but different percentages was used to prepare the mixes M9 to M12. The hybridization of three types of fibers which were steel fibers, palm fibers, and synthetic fibers (Barchip) was used to prepare the mixes M13-M16.

\section{Test Methods}

Each test result is represented by three cube samples $50 \mathrm{~mm}$ and tested to determine the compressive strength at 90 days of normal water curing and further 90 days and 180 days of seawater exposure. The flow test for the mixes was performed according to ASTM C230 [8] with a targeted flow of $150 \mathrm{~mm} \pm 10 \mathrm{~mm}$. The cube specimens were left in the moulds for 24 hours after casting at room temperature of $20^{\circ} \mathrm{C}$. After demoulding, the specimens were transferred into the water for curing until the age of the test. The compressive strength of the specimens were tested according to ASTM C109 [9] for each test age. The splitting tensile strength test was done by using $100 \times 200 \mathrm{~mm}$ cylinders according to ASTM C496 [10]. Whereas, the static modulus of elasticity 
TABLE 5: Mortar mixes proportions.

\begin{tabular}{lcccccccccc}
\hline Index & $\begin{array}{c}\text { Cement } \\
\left(\mathrm{Kg} / \mathrm{m}^{3}\right)\end{array}$ & $\begin{array}{c}\text { Silica fume } \\
\left(\mathrm{Kg} / \mathrm{m}^{3}\right)\end{array}$ & $\begin{array}{c}\text { Water } \\
\left(\mathrm{Kg} / \mathrm{m}^{3}\right)\end{array}$ & $\begin{array}{c}\text { SP } \\
(\%)\end{array}$ & $\begin{array}{c}\text { Sand } \\
\left(\mathrm{Kg} / \mathrm{m}^{3}\right)\end{array}$ & $\begin{array}{c}\mathrm{W}+\mathrm{S} \text { P/B } \\
\text { Steel fibre } \\
(\%)\end{array}$ & $\begin{array}{c}\text { Palm fibre } \\
(\%)\end{array}$ & $\begin{array}{c}\text { Synthetic fibre } \\
(\text { Barchip })\end{array}$ & $\begin{array}{c}\text { Flow } \\
(\mathrm{mm})\end{array}$ \\
\hline M0 & 550 & 55 & 260 & 1.8 & 1410 & 0.43 & 0 & - & - & 160 \\
M1 & 550 & 55 & 260 & 1.8 & 1410 & 0.43 & 0.25 & - & - & 155 \\
M2 & 550 & 55 & 260 & 1.8 & 1410 & 0.43 & 0.50 & - & - & 145 \\
M3 & 550 & 55 & 260 & 1.8 & 1410 & 0.43 & 0.75 & - & - & 145 \\
M4 & 550 & 55 & 260 & 2.0 & 1410 & 0.43 & 1.00 & - & - & 155 \\
M5 & 550 & 55 & 260 & 2.0 & 1410 & 0.43 & 1.25 & - & - & 150 \\
M6 & 550 & 55 & 260 & 2.0 & 1410 & 0.43 & 1.50 & - & - & 150 \\
M7 & 550 & 55 & 260 & 2.2 & 1410 & 0.43 & 1.75 & - & - & 145 \\
M8 & 550 & 55 & 260 & 2.2 & 1410 & 0.43 & 2.00 & - & - & 140 \\
M9 & 550 & 55 & 260 & 2.2 & 1410 & 0.43 & 1.75 & 0.25 & - & 140 \\
M10 & 550 & 55 & 260 & 2.2 & 1410 & 0.43 & 1.50 & 0.50 & - & 145 \\
M11 & 550 & 55 & 260 & 2.2 & 1410 & 0.43 & 1.25 & 0.75 & - & 145 \\
M12 & 550 & 55 & 260 & 2.2 & 1410 & 0.43 & 1.0 & 1.0 & - & 150 \\
M13 & 550 & 55 & 260 & 2.2 & 1410 & 0.43 & 1.0 & 0.5 & 0.5 & 145 \\
M14 & 550 & 55 & 260 & 2.2 & 1410 & 0.43 & 1.25 & 0.5 & 0.25 & 145 \\
M15 & 550 & 55 & 260 & 2.2 & 1410 & 0.43 & 1.25 & 0.25 & 0.5 & 145 \\
M16 & 550 & 55 & 260 & 2.2 & 1410 & 0.43 & 1.5 & 0.25 & 0.25 & 140 \\
\hline
\end{tabular}

test was achieved using $150 \times 300 \mathrm{~mm}$ cylinders according to ASTM C469 [11]. The flexural strength of the specimens was conducted using $40 \mathrm{~mm} \times 40 \mathrm{~mm} \times 160 \mathrm{~mm}$ samples conforming to ASTM C348 [12]. The absorption and voids ratio tests were carried out according to ASTM C642 [13]. Consequently, the ultrasonic pulse velocity test was carried out according to BS EN 12504-4: 2004 [14]. The average of three cubic specimens $(100 \mathrm{~mm})$ was taken for each of the latter tests.

\section{Results and Discussion}

4.1. Effect of Fibers on Flowability. The results of flow of the mortar mixes are shown in Table 5. It is clear to note that the inclusion of steel fiber in the high-strength flowable mortar (HSFM) mixes reduces the flowability. The increase in steel fiber inclusions in the mortar mixes results in reduction in flow results. And thus, higher dosage of SP is needed to achieve the required flowability. The comparison between the control mortars (M0) with steel fiber mortar of $2 \%$ vol. (M8) shows that the flow results dropped from $160 \mathrm{~mm}$ to $140 \mathrm{~mm}$ despite of increasing of SP dosage from $1.8 \%$ to $2.2 \%$, respectively. On the other hand, in mortar mixes with hybrid fibers, higher amount of palm fibers makes better flowability. Therefore, with a certain dosage of SP, the mix with $1 \%$ steel fibers with $1 \%$ palm fibers (M12) gives higher flowability than that of (M8) $[15,16]$.

The effect of the inclusion of palm and Barchip fibers (M13-M16) on the flowability of mortar was found to be better than that of steel fibers. Therefore, the inclusion of palm and Barchip fibers provides better flowing or working capacity than that of the mixes with only steel fiber $[15,16]$.

\subsection{Mechanical Properties of HSFM (Normal Curing)}

4.2.1. Compressive Strength. The results of the compressive strength of HSFM mixes show that the incorporation of steel fibers increases the compressive strength due to the improvement in the mechanical bond strength between the steel fibers and mortar where the fibers contribute to delay of microcrack formation and arrest their propagation afterwards up to a certain extent of fiber volume fraction $[17,18]$. Therefore, the results showed that the maximum value of the compressive strength was obtained by using $1.25 \%$ of steel fiber in the HSFM. The results of hybrid fiber (M9-M16) in the HSFM also indicate that the use of low-volume fraction of palm fiber or palm and Barchip fibers $(0.25 \%$ to $0.5 \%)$ improves the compressive strength as observed from mixes. This is down to the fact that hybrid fibers with different sizes and types offer different restrain [19].

4.2.2. Splitting Tensile Strength. The splitting tensile strength results of the HSFM mixes show that there is a significant increase in splitting tensile strength by the inclusion of fibers. The results of steel fiber-mortar mixes show that as the splitting tensile strength of flowable mortar increases as the steel fibers inclusions increase. Therefore, the effect of using $2 \%$ of steel fiber on the splitting tensile strength is the most significant. The increases in splitting tensile strength by using this percentage of steel fiber (M8) were found to be as much as $38 \%$ higher than that of the control mortar mix (M0) in the latter ages $[18,19]$. On the other hand, the hybridization of $1.5 \%$ steel fiber with the $0.5 \%$ of palm fiber or combination of palm and Barchip fibers increases the splitting tensile strength significantly. The percentage increases of the latter 
TABLE 6: Ultrasonic, absorption, and voids for HSFM.

\begin{tabular}{|c|c|c|c|c|c|c|}
\hline Mix type & SF $(\%)$ & $\mathrm{PF}(\%)$ & $\mathrm{BF}(\%)$ & Ultrasonic $(\mathrm{m} / \mathrm{s}) 90$ days & Absorption (\%) 90 days & Voids (\%) 90 days \\
\hline M0 & - & - & - & 3770 & 10.62 & 20.3 \\
\hline M1 & 0.25 & - & - & 3860 & 10.54 & 19.86 \\
\hline M2 & 0.50 & - & - & 3920 & 10.14 & 19.56 \\
\hline M3 & 0.75 & - & - & 4030 & 9.93 & 19.17 \\
\hline M4 & 1.0 & - & - & 4070 & 9.81 & 19.10 \\
\hline M5 & 1.25 & - & - & 4280 & 9.56 & 18.98 \\
\hline M6 & 1.50 & - & - & 4190 & 9.32 & 18.53 \\
\hline M7 & 1.75 & - & - & 4130 & 9.21 & 18.38 \\
\hline M8 & 2.0 & - & - & 4110 & 9.1 & 16.78 \\
\hline M9 & 1.75 & 0.25 & - & 4140 & 9.18 & 17.73 \\
\hline M10 & 1.50 & 0.50 & - & 4100 & 9.22 & 18.14 \\
\hline M11 & 1.25 & 0.75 & - & 4080 & 9.45 & 18.74 \\
\hline M12 & 1.0 & 1.0 & - & 4060 & 9.6 & 18.92 \\
\hline M13 & 1.0 & 0.50 & 0.50 & 4020 & 9.54 & 18.81 \\
\hline M14 & 1.25 & 0.50 & 0.25 & 4080 & 9.36 & 18.37 \\
\hline M15 & 1.25 & 0.25 & 0.50 & 4100 & 9.28 & 18.22 \\
\hline M16 & 1.50 & 0.25 & 0.25 & 4160 & 9.14 & 17.32 \\
\hline
\end{tabular}

TABLE 7: Compressive strength of HSFM exposed to seawater.

\begin{tabular}{|c|c|c|c|c|c|c|}
\hline Mix type & SF $(\%)$ & $\mathrm{PF}(\%)$ & $\mathrm{BF}(\%)$ & $\begin{array}{c}\text { Compressive strength } \\
\text { (MPa) 90-day normal water } \\
\text { curing }\end{array}$ & $\begin{array}{c}\text { Compressive strength (MPa) } \\
180 \text { days ( } 90 \text {-day normal water } \\
\text { curing }+90 \text {-day seawater curing) }\end{array}$ & $\begin{array}{c}\text { Compressive strength }(\mathrm{MPa}) \\
270 \text { days }(90 \text {-day normal water } \\
\text { curing }+180 \text {-day seawater curing) }\end{array}$ \\
\hline M0 & - & - & - & 59.6 & 58.1 & 53.3 \\
\hline M1 & 0.25 & - & - & 66.5 & 64.3 & 61.2 \\
\hline M2 & 0.50 & - & - & 68.1 & 64.7 & 62.4 \\
\hline M3 & 0.75 & - & - & 69.1 & 65.1 & 63.2 \\
\hline M4 & 1.0 & - & - & 70.4 & 66.1 & 64.3 \\
\hline M5 & 1.25 & - & - & 71.8 & 66.0 & 64.6 \\
\hline M6 & 1.50 & - & - & 68.4 & 64.5 & 62.1 \\
\hline M7 & 1.75 & - & - & 66.1 & 63.6 & 61.1 \\
\hline M8 & 2.0 & - & - & 61.4 & 58.6 & 56.7 \\
\hline M9 & 1.75 & 0.25 & - & 65.6 & 62.9 & 60.1 \\
\hline M10 & 1.50 & 0.50 & - & 67.7 & 65.5 & 63.0 \\
\hline M11 & 1.25 & 0.75 & - & 61.1 & 59.5 & 57.3 \\
\hline M12 & 1.0 & 1.0 & - & 60.9 & 58.7 & 57.2 \\
\hline M13 & 1.0 & 0.50 & 0.50 & 59.8 & 58.2 & 56.7 \\
\hline M14 & 1.25 & 0.50 & 0.25 & 61.9 & 60.4 & 58.8 \\
\hline M15 & 1.25 & 0.25 & 0.50 & 63.8 & 61.7 & 60.7 \\
\hline M16 & 1.50 & 0.25 & 0.25 & 68.2 & 65.9 & 64.0 \\
\hline
\end{tabular}

cases (M10 and M16) were found to be higher than that of the control mix (M0) by about $46 \%$ and $60 \%$, respectively. This can be attributed to the ability of mortar with two fibers to bridge the cracks effectively; thus, the micromechanical feature of cracks bridging are operative from the stage of damage evolution to beyond ultimate loading [20].

4.2.3. Flexural Strength. The flexural strength results of HSFM mortar mixes show that the increase of the flexural strength is compatible with the increase of steel fiber volume fractions. The increase of the flexural strength of the mix containing $1.75 \%$ volumetric fraction of steel fiber (M7) is about $102 \%$ higher than the control mix (M0), and this is possibly due to the better compaction and homogeneity of fiber distribution in HSFM $[17,20]$.

However, the results of hybrids fibers indicate that the increases in flexural strength are much effective. It can be noticed that the increase in flexural strength by hybrid fibers containing $1.5 \%$ steel fiber $+0.5 \%$ palm fiber was found to be 
TABLE 8: Splitting tensile strength of HSFM exposed to seawater.

\begin{tabular}{|c|c|c|c|c|c|c|}
\hline Mix type & $\mathrm{SF}(\%)$ & $\mathrm{PF}(\%)$ & $\mathrm{BF}(\%)$ & $\begin{array}{l}\text { Splitting tensile strength } \\
(\mathrm{MPa}) 90 \text { days }\end{array}$ & $\begin{array}{l}\text { Splitting tensile strength }(\mathrm{MPa}) \\
180 \text { days }(90 \text {-day normal water } \\
\text { curing }+90 \text {-day seawater curing) }\end{array}$ & $\begin{array}{l}\text { Splitting tensile strength }(\mathrm{MPa}) \\
270 \text { days }(90 \text {-day normal water } \\
\text { curing + 180-day seawater curing) }\end{array}$ \\
\hline M0 & - & - & - & 2.34 & 2.28 & 2.22 \\
\hline M1 & 0.25 & - & - & 2.46 & 2.41 & 2.36 \\
\hline M2 & 0.50 & - & - & 2.68 & 2.62 & 2.58 \\
\hline M3 & 0.75 & - & - & 2.78 & 2.72 & 2.68 \\
\hline M4 & 1.0 & - & - & 2.90 & 2.86 & 2.81 \\
\hline M5 & 1.25 & - & - & 2.96 & 2.88 & 2.85 \\
\hline M6 & 1.50 & - & - & 3.0 & 2.91 & 2.87 \\
\hline M7 & 1.75 & - & - & 3.12 & 3.04 & 2.97 \\
\hline M8 & 2.0 & - & - & 3.21 & 3.11 & 3.02 \\
\hline M9 & 1.75 & 0.25 & - & 3.33 & 3.26 & 3.16 \\
\hline M10 & 1.50 & 0.50 & - & 3.41 & 3.37 & 3.27 \\
\hline M11 & 1.25 & 0.75 & - & 2.79 & 2.75 & 2.70 \\
\hline M12 & 1.0 & 1.0 & - & 2.65 & 2.62 & 2.59 \\
\hline M13 & 1.0 & 0.50 & 0.50 & 2.87 & 2.81 & 2.80 \\
\hline M14 & 1.25 & 0.50 & 0.25 & 2.93 & 2.86 & 2.84 \\
\hline M15 & 1.25 & 0.25 & 0.50 & 3.08 & 2.98 & 2.97 \\
\hline M16 & 1.50 & 0.25 & 0.25 & 3.74 & 3.66 & 3.59 \\
\hline
\end{tabular}

TABle 9: Flexural strength of high-strength flowable mortar exposed to seawater.

\begin{tabular}{|c|c|c|c|c|c|c|}
\hline Mix type & SF $(\%)$ & $\mathrm{PF}(\%)$ & $\mathrm{BF}(\%)$ & $\begin{array}{l}\text { Flexural strength (MPa) } \\
\text { 90-day normal water curing }\end{array}$ & $\begin{array}{c}\text { Flexural strength }(\mathrm{MPa}) \\
180 \text { days }(90 \text {-day normal water } \\
\text { curing }+90 \text {-day seawater curing) }\end{array}$ & $\begin{array}{c}\text { Flexural strength (MPa) } 270 \text { days } \\
\text { (90-day normal water curing }+ \\
\text { 180-day seawater curing) }\end{array}$ \\
\hline M0 & - & - & - & 9.12 & 8.96 & 8.50 \\
\hline M1 & 0.25 & - & - & 9.88 & 9.64 & 9.22 \\
\hline M2 & 0.50 & - & - & 11.24 & 11.02 & 10.50 \\
\hline M3 & 0.75 & - & - & 12.68 & 12.32 & 11.92 \\
\hline M4 & 1.0 & - & - & 14.43 & 13.95 & 13.60 \\
\hline M5 & 1.25 & - & - & 14.85 & 14.28 & 13.90 \\
\hline M6 & 1.50 & - & - & 15.33 & 14.72 & 14.25 \\
\hline M7 & 1.75 & - & - & 18.42 & 17.72 & 17.11 \\
\hline M8 & 2.0 & - & - & 17.36 & 16.56 & 16.0 \\
\hline M9 & 1.75 & 0.25 & - & 17.64 & 17.10 & 16.51 \\
\hline M10 & 1.50 & 0.50 & - & 19.22 & 18.70 & 18.15 \\
\hline M11 & 1.25 & 0.75 & - & 14.95 & 14.58 & 14.16 \\
\hline M12 & 1.0 & 1.0 & - & 13.26 & 12.85 & 12.65 \\
\hline M13 & 1.0 & 0.50 & 0.50 & 14.15 & 13.90 & 13.52 \\
\hline M14 & 1.25 & 0.50 & 0.25 & 15.11 & 14.70 & 14.30 \\
\hline M15 & 1.25 & 0.25 & 0.50 & 15.24 & 14.81 & 14.50 \\
\hline M16 & 1.50 & 0.25 & 0.25 & 19.67 & 19.15 & 18.50 \\
\hline
\end{tabular}

about $107 \%$ higher than that of the control mortar. Consequently, the flexural strengths of hybrid fibers HSFM by using steel fibers, palm fibers, and Barchip fibers showed that the highest increase in flexural strength is $116 \%$, which was derived from the mix containing hybrid fibers of $1.5 \%$ steel fibers $+0.25 \%$ palm fibers $+0.25 \%$ Barchip fibers. This effective increase in flexural strength maybe resulted from better compaction and homogeneity of fibers distribution in mortar mixes and the ability of different types of fibers to restrain and bridge the cracks [17].

4.2.4. Static Modulus of Elasticity. The moduli of elasticity results showed that there is a significant improvement in 
TABLE 10: Static modulus of elasticity $\left(E_{c}\right)$ of high-strength flowable mortar exposed to seawater.

\begin{tabular}{|c|c|c|c|c|c|c|}
\hline Mix type & $\mathrm{SF}(\%)$ & $\mathrm{PF}(\%)$ & $\mathrm{BF}(\%)$ & $\begin{array}{l}\text { Static modulus of elasticity, } \\
E_{c},(\mathrm{GPa}) 90 \text {-day normal } \\
\text { water curing }\end{array}$ & $\begin{array}{c}\text { Static modulus of elasticity, } \\
E_{c},(\mathrm{GPa}) 180 \text { days }(90 \text {-day } \\
\text { normal water curing }+90 \text {-day } \\
\text { seawater curing) }\end{array}$ & $\begin{array}{c}\text { Static modulus of elasticity, } E_{c} \text {, } \\
(\mathrm{GPa}) 270 \text { days }(90 \text {-day normal } \\
\text { water curing }+180 \text {-day } \\
\text { seawater curing) }\end{array}$ \\
\hline M0 & - & - & - & 36.3 & 35.8 & 34.1 \\
\hline M1 & 0.25 & - & - & 36.8 & 35.9 & 34.6 \\
\hline M2 & 0.50 & - & - & 38.1 & 36.9 & 35.9 \\
\hline M3 & 0.75 & - & - & 38.9 & 37.7 & 36.9 \\
\hline M4 & 1.0 & - & - & 40.1 & 39.0 & 37.9 \\
\hline M5 & 1.25 & - & - & 41.1 & 39.9 & 38.7 \\
\hline M6 & 1.50 & - & - & 43.7 & 42.1 & 41.0 \\
\hline M7 & 1.75 & - & - & 45.2 & 44.0 & 42.3 \\
\hline M8 & 2.0 & - & - & 46.3 & 44.7 & 42.9 \\
\hline M9 & 1.75 & 0.25 & - & 48.3 & 46.8 & 45.3 \\
\hline M10 & 1.50 & 0.50 & - & 45.8 & 44.9 & 43.2 \\
\hline M11 & 1.25 & 0.75 & - & 43.0 & 42.0 & 41.0 \\
\hline M12 & 1.0 & 1.0 & - & 42.2 & 41.3 & 40.5 \\
\hline M13 & 1.0 & 0.50 & 0.50 & 41.5 & 40.4 & 39.9 \\
\hline M14 & 1.25 & 0.50 & 0.25 & 48.4 & 47.2 & 46.2 \\
\hline M15 & 1.25 & 0.25 & 0.50 & 49.7 & 48.6 & 47.6 \\
\hline M16 & 1.50 & 0.25 & 0.25 & 51.7 & 50.6 & 49.1 \\
\hline
\end{tabular}

static modulus of elasticity for HSFM mixes by the inclusion of the steel fibers. The comparison between (M0) and (M8) shows that the use of $2.0 \%$ steel fibers leads to an increase in static modulus of elasticity. The static modulus of elasticity increased by about $28 \%$ with the inclusion of steel fibers. This could be due to the fact that steel fibers have high stiffness resulting in a higher modulus of elasticity for HSM [21]. However, the effect of using hybrid fibers on the static modulus of elasticity indicated that the use of $0.25 \%$ of palm fibers or $0.5 \%$ of palm fibers and Barchip fibers in hybrid combination was found to be much affective. The increase percentages in static modulus of elasticity for these uses were found to be $33 \%$ and $42 \%$, respectively. This is probably due to the optimization of these percentages of fibers to operate the higher bond strength behavior and thus a higher modulus of elasticity [22].

4.2.5. Ultrasonic Pulse Velocity Test. The ultrasonic test results for all HSFM are given in Table 6. The results showed that the steel fibers enhanced the results for the velocity of ultrasonic test as shown in Figure 1. Therefore, the inclusion of $2 \%$ vol. of steel fibers in HSFM mixes increased the ultrasonic velocity from $3770 \mathrm{~m} / \mathrm{s}$ to $4110 \mathrm{~m} / \mathrm{s}$. However, the greatest value of ultrasonic pulse velocity test $(4280 \mathrm{~m} / \mathrm{s})$ was obtained when $1.25 \%$ vol. of steel fibers was used. This result was compatible to the same percentage that gives highest compressive strength due to the improvement in the mechanical bond strength between the steel fibers and mortar obtained by this inclusion of the steel fibers [17, 18].

The results for all hybrid fibers also show that the ultrasonic results increases with the fibers inclusions. The highest

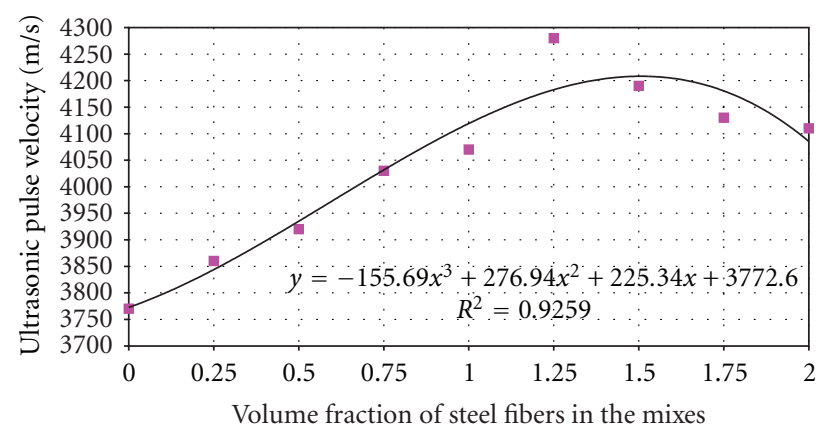

FIGURE 1: Relation between volume fraction of steel fiber and ultrasonic pulse velocity for HSFM at 90 days.

value of hybrid fibers for HSFM was $4160 \mathrm{~m} / \mathrm{s}$, which was obtained in mortar mix (M16) using 1.50\% steel fiber + $0.25 \%$ palm fiber $+0.25 \%$ Barchip fiber. In general, for the all hybrid fibers (HSFM reinforced with steel fibers + palm fibers and also HSFM reinforced with steel fibers + palm fibers + Barchip fibers), the ultrasonic pulse velocity is also related to compressive strength as illustrated in Figure 2.

4.2.6. Absorption and Voids Ratio. The results of the absorption and voids ratio of HSFM mixes are shown in Table 6. It can be noted that the use of steel fibers reduced the absorption and void ratios as the volume percentage of steel fiber inclusion increased as shown in Figure 3. The comparison between (M0) and (M8) shows that the use of $2 \%$ vol. of steel fiber lowered the absorption and voids ratio from $10.62 \%$ and $20.3 \%$ to $9.1 \%$ and $16.72 \%$, respectively. This 


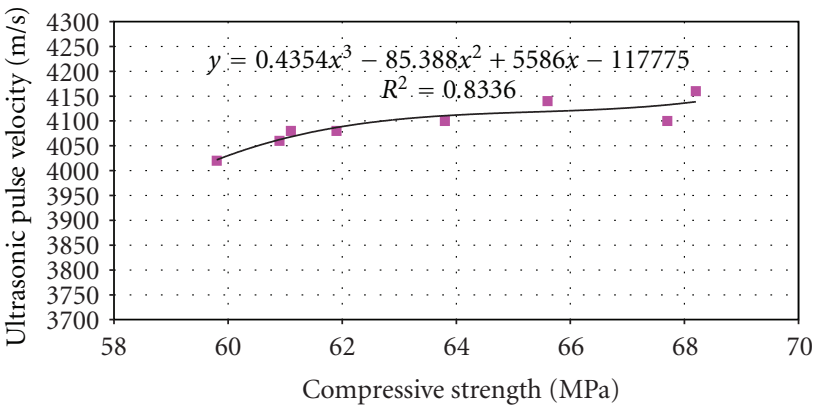

Figure 2: Relationship between compressive strength and ultrasonic pulse velocity for HSFM reinforced by hybrid fibres.

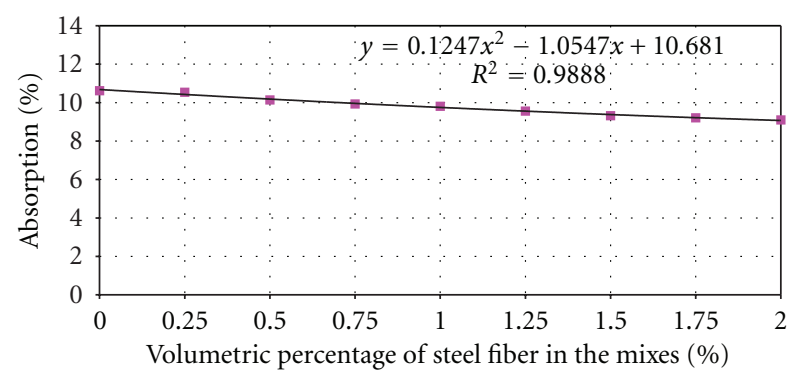

FIGURE 3: Relationship between volume fraction of steel fibre and percentage of absorption for HSFM.

could be due to the fact that steel fibers reduce the porosity of the HSFM by using these fibers [23]. On the other hand, the absorption and void ratios reduction can be also seen in hybrid fiber mixes, and it was found that the Barchip fibers have better ability to improve these properties than that of palm fibers in all hybrid HSFM mixes. The effects of using HSFM reinforced by different hybrid fibers are given in Figures 4 and 5.

4.2.7. Seawater Exposure Effects. The results of the HSFM mixes exposed to seawater are represented from Tables 7 , 8,9 , and 10 . The reduction in compressive strength for the HSFM mixes was between 5-10\% after 180 days of exposure to seawater is presented in Figure 6. The use of hybrid fibers recorded the minimum reductions in compressive strength, which were obtained from the mixes of hybrid fibers in both cases of using steel fibers with palm fibers and also the use of steel, palm, and Barchip fibers. This is possibly due to ability of different types of fibers reinforcement to make the mortar more impermeable [24].

The results of the splitting tensile strength of mortar mixes showed that the effect of seawater on the splitting tensile strength was marginal. However, it can be seen from Figure 7 that the reduction in splitting tensile strength was between $2-6 \%$. The maximum reduction obtained in case of using $2 \%$ steel fibers in the mortar mixes. This is maybe due to the corrosion of surface steel, fibers which reduce the splitting tensile strength of mortar and may cause some spalling of the concrete surface $[5,24]$. Therefore, the hybrid fibers mixes with $1 \%$ steel fiber with $1.0 \%$ of either palm fiber

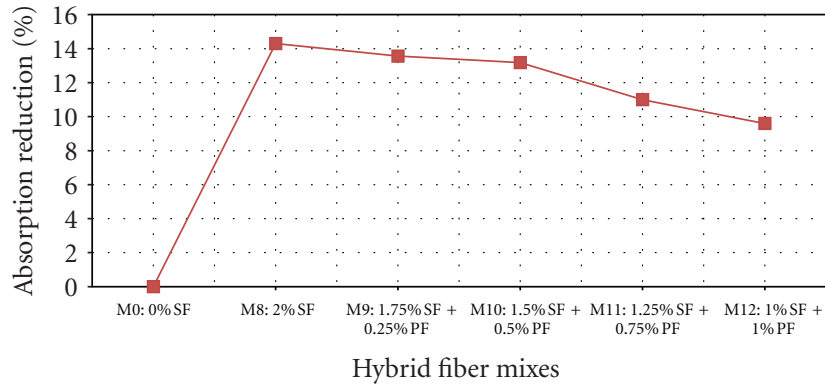

FIgURE 4: Absorption reduction percentage of HSFM by using hybrid fibres [steel fibres (SF) + palm fibres (PF)].

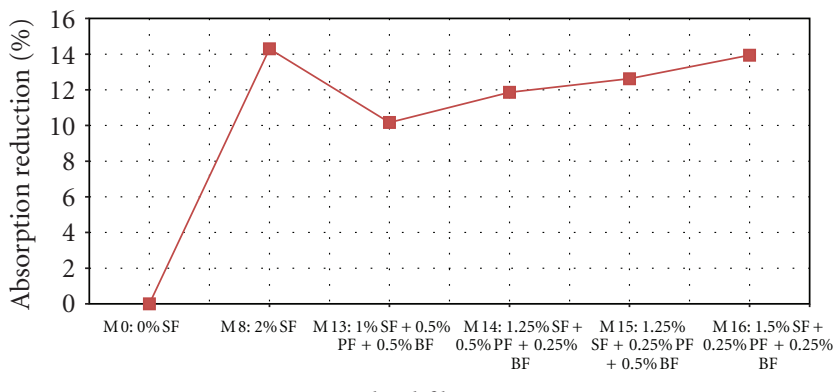

Hybrid fiber mixes

FIGURE 5: Absorption reduction percentage of HSFM by using hybrid fibres [steel fibres $(\mathrm{SF})+$ palm fibres $(\mathrm{PF})+$ Barchip fibres $(\mathrm{BF})]$.

or combination of palm and Barchip fibers (M12 and M13) gave the minimum reduction among other mixes.

In addition, the results of the flexural strength of mortar indicated that the reduction of about $4.5-8 \%$ was obtained for the flexural strength of HSFM exposed to seawater. The flexural strength reduction of the mixes is shown in Figure 8. From this figure, it can be seen that the maximum reduction in flexural strength of HSFM obtained also when the monosteel fibers used as $2 \%$ in mortar mixes. The reduction of flexural strength was about $8 \%$ after 180 days of seawater exposure. This is also was found by other researchers [25], where the surface deterioration of steel fibers is worse under sustained flexural stress due to the increased cracking and vulnerability of steel fibers. Therefore, the hybridization of different types of fibers improves the resistance of the HSFM as it can be noted for the results of the mortar mixes with hybrid fibers of steel and palm fibers and also for the use of steel fiber + palm fiber + Barchip fiber.

The results of static modulus of elasticity show that there is a reduction between $4-7 \%$ in elastic modulus of elasticity of mortar after 180 days of exposure to seawater as shown in Figure 9. The minimum reduction of static modulus of elasticity was also obtained for the mixes of hybrid fibers of $1 \%$ steel, palm with $1 \%$ of either palm fiber, or a combination of palm and Barchip fibers. This is also can be attributed to the same causes listed above, where the palm and Barchip fibers have better durability performance against the seawater $[5,24]$. 


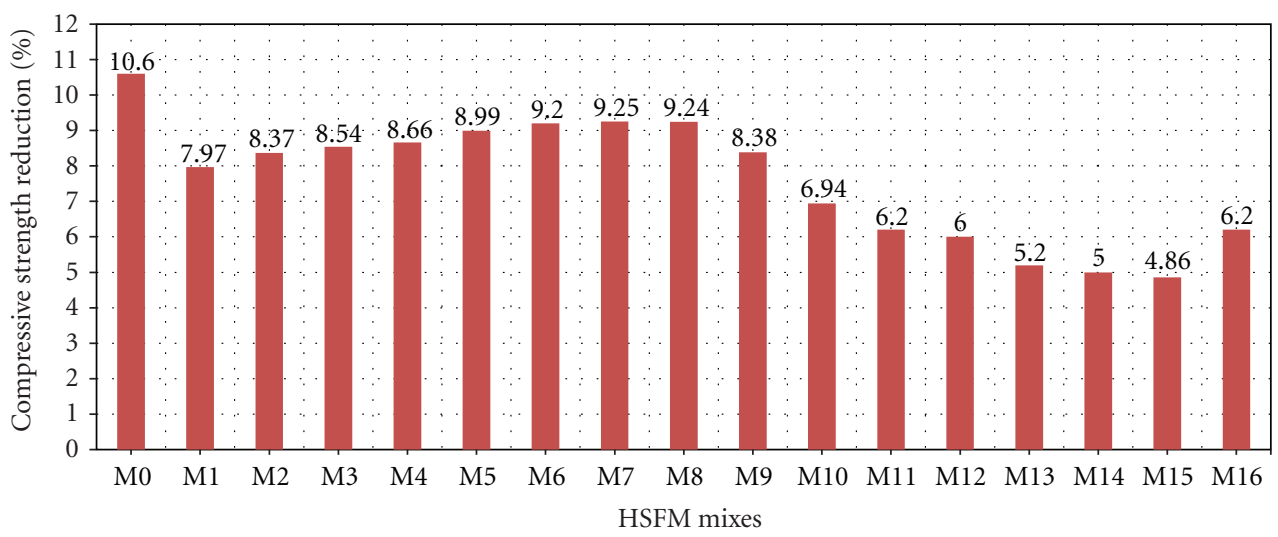

FIGURE 6: Compressive strength reduction percentage of HSFM after exposure to seawater.

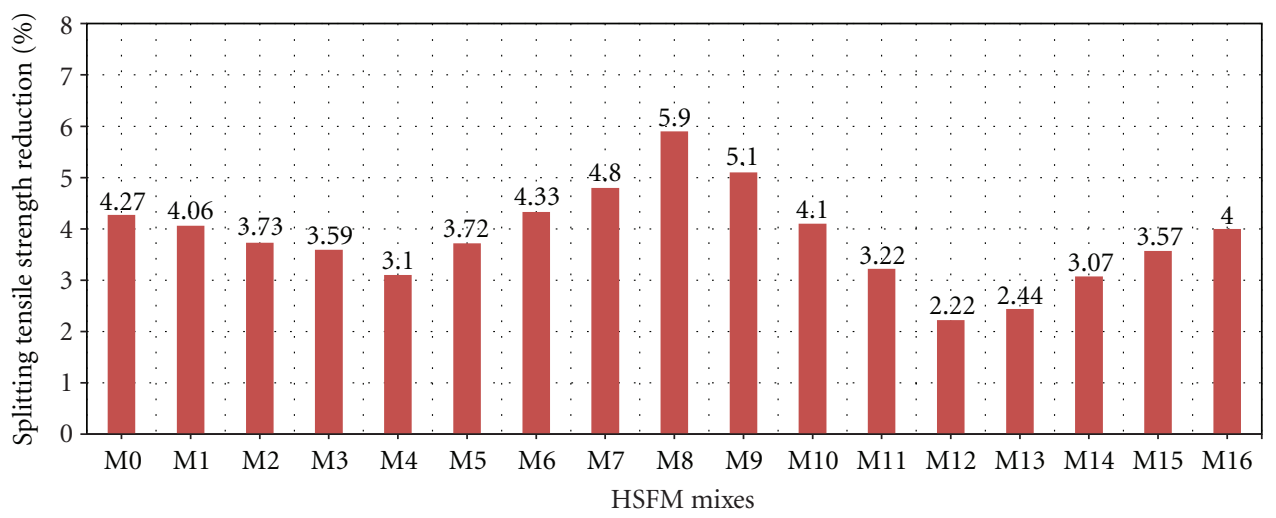

FIGURE 7: Splitting tensile strength reduction percentage of HSFM after exposure to seawater.

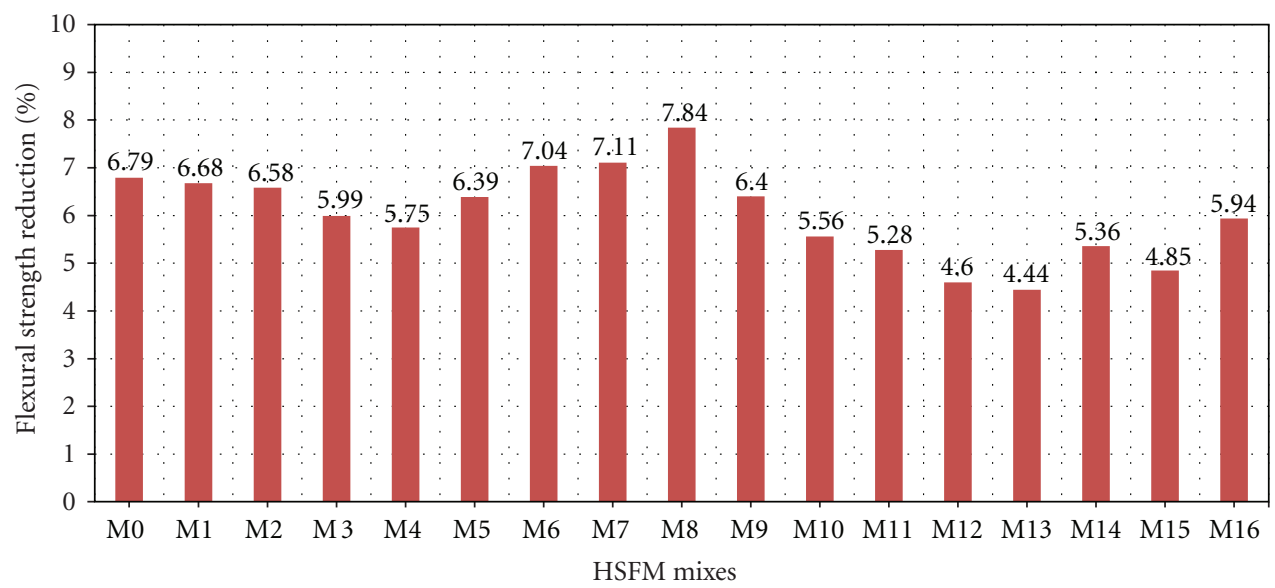

FIGURE 8: Flexural strength reduction percentage of HSFM after exposure to seawater.

\section{Conclusions}

The study of high-strength flowable mortar (HSFM) reinforced by various fibers was carried out to understand the different mechanical properties and the durability of HSFM exposed to seawater. The major findings of this study are (i) the compressive strength results for HSFM show that the use of the steel fibers increases the compressive strength. The highest increase (about 21\%) was obtained for the HSFM mixes with $1.25 \%$ of steel fiber. The compressive strength results of HSFM reinforced by hybrid fibers of $1.5 \%$ steel fibers $+0.25 \%$ 


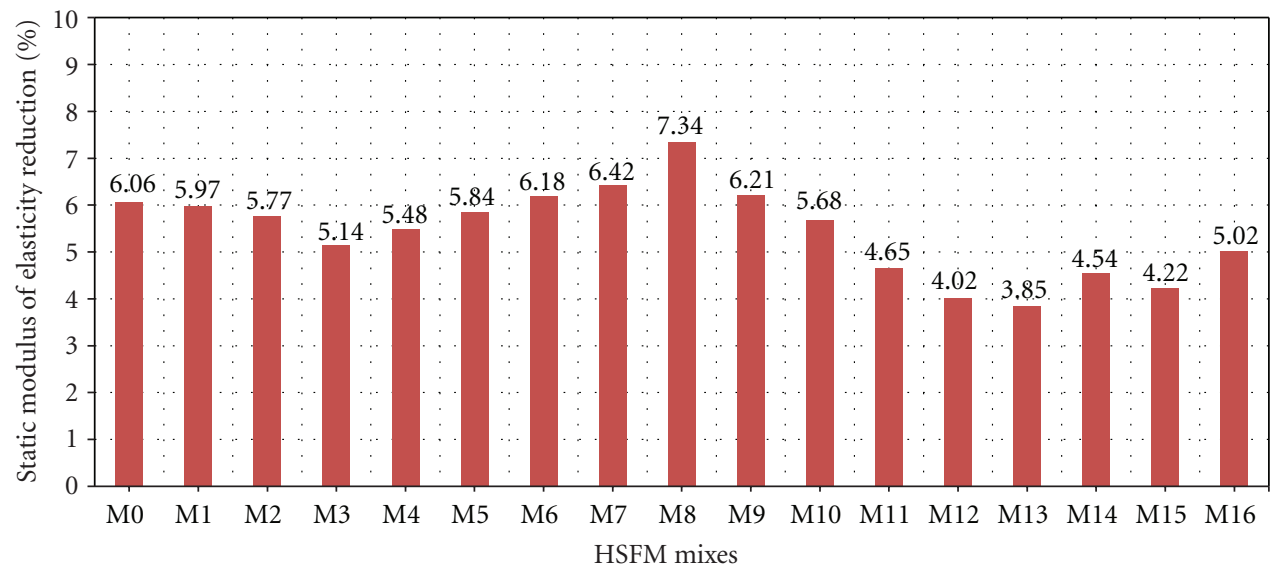

FIGURE 9: Static modulus of elasticity reduction percentage of HSFM after exposure to seawater.

palm fibers $+0.25 \%$ Barchip fibers provide a significant increase in the compressive strength of cement mortar;

(ii) the flexural strength of HSFM mixes containing steel fibers increased with the increasing volume fraction. The highest values for these properties were obtained when $1.75 \%$ of steel fiber was included in the mix. Whereas, the flexural strength of HSFM of hybrid fibers $(1.5 \%$ steel fiber $+0.25 \%$ palm fiber $+0.25 \%$ Barchip fibers) boasts the highest flexural strength compared to other HSFM mixes;

(iii) the hybridization of $1.5 \%$ steel fibers with the $0.5 \%$ of palm fibers for the HSFM increases the splitting tensile strength by about $38 \%$. Whereas the hybrid fibers of $1.5 \%$ steel fibers $+0.25 \%$ palm fibers $+0.25 \%$ Barchip fibers increases the splitting tensile strength by about $60 \%$;

(iv) hybridization was also found to be effective in enhancing the modulus of elasticity of HSFM. Combining the volume fractions of $1.75 \%$ steel fiber and $0.25 \%$ palm fibers or $1.5 \%$ steel fibers, $0.25 \%$ palm fibers and $0.25 \%$ Barchip fibers increases the static modulus of elasticity by about $33 \%$ and $42 \%$, respectively;

(v) the results indicated that the steel fibers improved the results of the velocity of the ultrasonic test. The ultrasonic velocity increased from $3770 \mathrm{~m} / \mathrm{s}$ to $4190 \mathrm{~m} / \mathrm{s}$ from the inclusion of $2 \%$ vol. of steel fibers in HSFM mixes. The highest value of the ultrasonic pulse velocity test $(4280 \mathrm{~m} / \mathrm{s})$ was obtained when $1.25 \%$ vol. of steel fibers was used;

(vi) the inclusion of $2 \%$ of steel fibers in HSFM reduced the absorption and voids ratio from $10.62 \%$ and $20.3 \%$ to $9.1 \%$ and $16.72 \%$, respectively. Besides the reduction of absorption and voids ratio, it was also observed that the Barchip fibers have better ability to improve these properties than palm fibers in all hybrid HSFM mixes tested; (vii) in terms of durability, after seawater exposure, the minimum reduction in compressive strength was obtained for the HSFM mixes of hybrid fibers in the cases of using steel fibers with palm fibers and also for the use of steel, palm, and Barchip fibers;

(viii) the reduction in splitting tensile strength and flexural strength for HSFM was between 2-6\%, and the maximum reduction was obtained in case of using $2 \%$ steel fibers in the mortar mixes. Besides, the reduction in static modulus of elasticity for HSFM was between 3-8\% in the modulus of elasticity of mortar after 180 days of exposure to seawater. The minimum reduction of static modulus of elasticity was also obtained for the HSFM mixes of hybrid fibers of steel, palm, and Barchip fibers.

\section{Disclosure}

The paper has not been previously published, is not currently submitted for review in any other journal, and will not be submitted elsewhere before any decision is made by the authors of this journal.

\section{Acknowledgment}

The work described in this paper was a part of Ph.D. research program of the first author which is supported by a research grant and USM fellowship from the Universiti Sains Malaysia.

\section{References}

[1] S. K. Al-Oraimi and A. C. Seibi, "Mechanical characterisation and impact behaviour of concrete reinforced with natural fibres," Composite Structures, vol. 32, no. 1-4, pp. 165-171, 1995.

[2] A. C. Aydin, "Self compactability of high volume hybrid fiber reinforced concrete," Construction \& Building Materials, vol. 21, no. 6, pp. 1149-1154, 2007. 
[3] S. P. Shah and A. E. Naaman, "Mechanical properties of glass and steel fiber reinforced mortar," American Concrete Institute Journal, vol. 73, no. 1, pp. 50-53, 1976.

[4] W. Yao, J. Li, and $\mathrm{K}$. Wu, "Mechanical properties of hybrid fiber-reinforced concrete at low fiber volume fraction," Cement and Concrete Research, vol. 33, no. 1, pp. 27-30, 2003.

[5] M. T. Bassuoni and M. L. Nehdi, "Durability of self-consolidating concrete to sulfate attack under combined cyclic environments and flexural loading," Cement and Concrete Research, vol. 39, no. 3, pp. 206-226, 2009.

[6] J. Sustersic, V. Jovicic, A. Zajc et al., "Evaluation of improvement in the bearing capacity of fiber reinforced shotcrete tunnel lining," in Proceedings of the 6th International RILEM Symposium, Fiber-Reinforced Concrete, Ed., vol. 2, pp. 985994, Reunion Internationale des Laboratoires et Experts des Materiaux (RILEM), Varenna, Italy, September 2004.

[7] The American Concrete Institute (ACI 211.1-91), "Standard practice for selecting proportions for normal, heavyweight, and mass concrete," ACI manual of concrete practice, part 1: materials and general properties of concrete, 2000.

[8] ASTM C230, Standard Specification for Flow Table for Use in Tests of Hydraulic Cement, Annual Book of ASTM Standards, 2002.

[9] ASTM C109, Standard Test Method for Compressive Strength of Hydraulic Cement Mortars Using $50 \mathrm{~mm}$ Cube Specimens, Annual Book of ASTM Standards, 2002.

[10] ASTM C496, Standard Test Method for Splitting for Splitting Tensile Strength of Cylindrical Concrete Specimens, Annual Book of ASTM Standards, 2002.

[11] ASTM C469, Standard Test Method for Static Modulus of Elasticity and Poisson's Ratio of Concrete in Compression, Annual Book of ASTM Standards, 2002.

[12] ASTM C348, Standard Test Method for Flexural Strength of Hydraulic-Cement Mortars, Annual Book of ASTM Standards, 2002.

[13] ASTM C642, Standard Test Method for Density, Absorption, and Voids in Hardened Concrete, Annual Book of ASTM Standards, 2002.

[14] BS EN 12504-4, Determination of Ultrasonic Pulse Velocity, Testing Hardened Concrete, British Standards Institute, London, UK, 2004.

[15] E. T. Dawood and M. Ramli, "Development of high strength flowable mortar with hybrid fiber," Construction \& Building Materials, vol. 24, no. 6, pp. 1043-1050, 2010.

[16] E. T. Dawood and M. Ramli, "High strength characteristics of cement mortar reinforced with hybrid fibres," Construction \& Building Materials, vol. 25, no. 5, pp. 2240-2247, 2011.

[17] M. Sahmaran and I. O. Yaman, "Hybrid fiber reinforced selfcompacting concrete with a high-volume coarse fly ash," Construction \& Building Materials, vol. 21, no. 1, pp. 150-156, 2007.

[18] B. Felekoğlu, S. Türkel, and Y. Altuntaş, "Effects of steel fiber reinforcement on surface wear resistance of self-compacting repair mortars," Cement and Concrete Composites, vol. 29, no. 5, pp. 391-396, 2007.

[19] B. Chen and J. Liu, "Contribution of hybrid fibers on the properties of the high-strength lightweight concrete having good workability," Cement and Concrete Research, vol. 35, no. 5, pp. 913-917, 2005.

[20] I. Markovici, J. C. Walarven, and M. J. Van, "Self compacting hybrid fiber concrete-mix design, workability and mechanical properties," in Proceedings of the 3rd International Symposium on Self-compacting Concrete, pp. 763-775, 2003.
[21] O. Kayali, M. N. Haque, and B. Zhu, "Some characteristics of high strength fiber reinforced lightweight aggregate concrete," Cement and Concrete Composites, vol. 25, no. 2, pp. 207-213, 2003.

[22] M. C. Nataraja, N. Dhang, and A. P. Gupta, "Stress-strain curves for steel-fiber reinforced concrete under compression," Cement and Concrete Composites, vol. 21, no. 5-6, pp. 383-390, 1999.

[23] G. E. Nawy, Founamentals of High Strength High Performance Concrete, Longman House, Burnt Hill, Harlow, UK, 1996.

[24] M. Hoseini, V. Bindiganavile, and N. Banthia, "The effect of mechanical stress on permeability of concrete: a review," Cement and Concrete Composites, vol. 31, no. 4, pp. 213-220, 2009.

[25] C. Johnston, Fiber-Reinforced Cements and Concretes, Gordon and Breach Science Publications, Amsterdam, The Netherlands, 2001. 

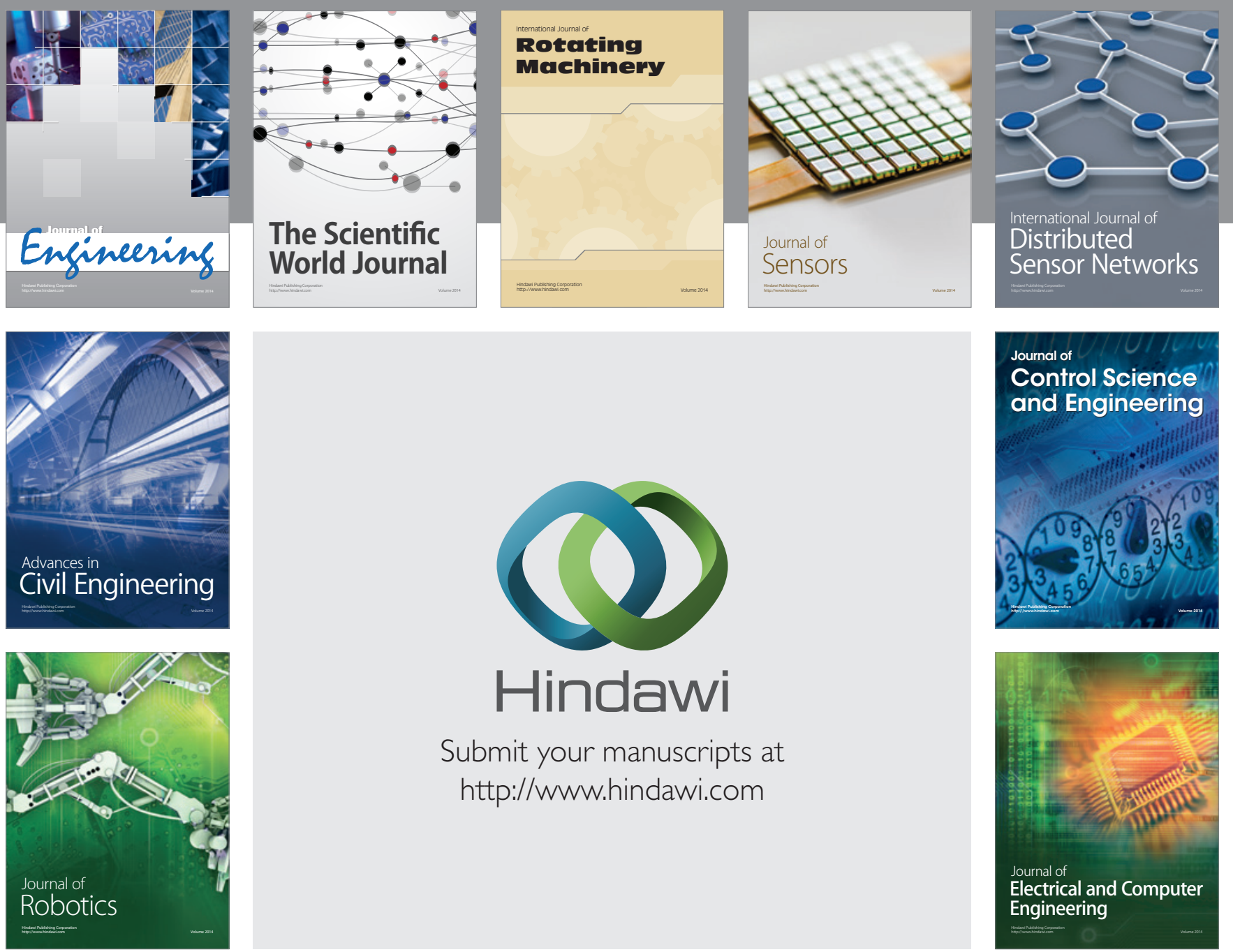

Submit your manuscripts at

http://www.hindawi.com
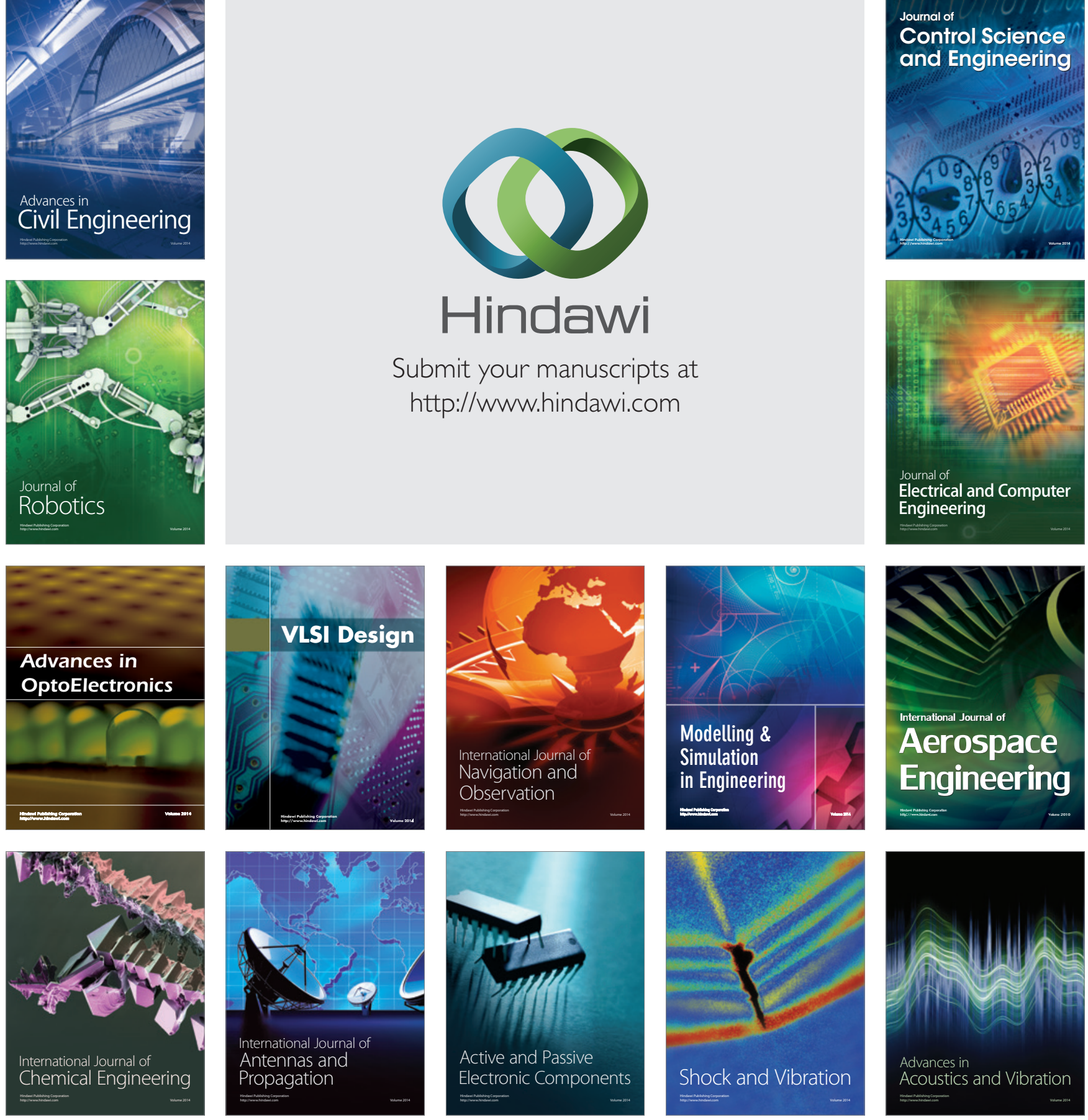